\title{
Effects of source on bioavailability of selenium, antioxidant status, and performance in lactating dairy cows during oxidative stress-inducing conditions
}

\author{
L. L. Sun, ${ }^{1}$ S. T. Gao, ${ }^{1}$ K. Wang, ${ }^{1}$ J. C. Xu, ${ }^{2}$ M. V. Sanz-Fernandez, ${ }^{3}$ L. H. Baumgard, ${ }^{4}$ and D. P. Bu ${ }^{1,5,6 *}$ \\ ${ }_{1}^{1}$ Institute of Animal Science, State Key Laboratory of Animal Nutrition, Chinese Academy of Agricultural Sciences, Beijing 100193, China \\ ${ }^{2}$ Key Laboratory of Economic Plants and Biotechnology, Kunming Institute of Botany, Chinese Academy of Sciences, Kunming 650201, China \\ ${ }^{3}$ Comparative Physiology Group, Subdireccion General de Investigacion y Tecnologia (SGIT), Instituto Nacional de Investigacion y Tecnologia \\ Agraria y Alimentaria (INIA), Madrid 28040, Spain \\ ${ }^{4}$ Department of Animal Science, lowa State University, Ames 50014 \\ ${ }^{5}$ Chinese Academy of Agricultural Sciences-World Agroforestry Centre (CAAS-ICRAF) Joint Lab on Agroforestry \\ and Sustainable Animal Husbandry, World Agroforestry Centre, East and Central Asia, Beijing 100193, China \\ ${ }^{6}$ Hunan Co-Innovation Center of Animal Production Safety (CICAPS), Changsha, Hunan 410128, China
}

\section{ABSTRACT}

In the current study, we used heat stress (HS) as an oxidative stress model to examine the effects of hydroxy-selenomethionine (HMSeBA), an organic selenium source, on selenium's bioavailability, antioxidant status, and performance when fed to dairy cows. Eight mid-lactation Holstein dairy cows $(141 \pm 27 \mathrm{~d}$ in milk, $35.3 \pm 2.8 \mathrm{~kg}$ of milk/d, parity 2 or 3 ) were individually housed in environmental chambers and randomly assigned to 1 of 2 treatments: inorganic Se supplementation (sodium selenite; SS; $0.3 \mathrm{mg}$ of Se/ $\mathrm{kg}$ of dry matter; $\mathrm{n}=4)$ or HMSeBA supplementation (0.3 mg of Se/ $\mathrm{kg}$ of dry matter; $\mathrm{n}=4)$. The trial was divided into 3 continuous periods: a covariate period $(9 \mathrm{~d})$, a thermal neutral (TN) period (28 d), and a HS period (9d). During the covariate and $\mathrm{TN}$ periods, all cows were housed in TN conditions $\left(20^{\circ} \mathrm{C}, 55 \%\right.$ humidity). During HS, all cows were exposed to cyclical HS conditions $\left(32-36^{\circ} \mathrm{C}\right.$, $40 \%$ humidity). All cows were fed SS during the covariate period, and dietary treatments were implemented during the TN and HS periods. During HS, cows fed HMSeBA had increased Se concentrations in serum and milk, and total Se milk-to-serum concentration ratio compared with SS controls. Superoxide dismutase activity did not differ between Se sources, but we noted a treatment by day interaction in glutathione peroxidase activity as HS progressively reduced it in SS controls, whereas it was maintained in HMSeBA cows. Supplementation with HMSeBA increased total antioxidant capacity and decreased malondialdehyde, hydrogen peroxide, and nitric oxide serum concentrations compared with SS-fed controls. We found no treatment effects

Received April 25, 2018.

Accepted September 7, 2018.

*Corresponding author: budengpan@126.com on rectal temperature, respiratory rate, or dry matter intake. Supplementing HMSeBA tended to increase milk yield and decrease milk fat percentage. No other milk composition parameters differed between treatments. We observed no treatment effects detected on blood biochemistry, except for a lower alanine aminotransferase activity in HMSeBA-fed cows. These results demonstrate that HMSeBA supplementation decreases some parameters of HS-induced oxidative stress.

Key words: dairy cow, hydroxy-selenomethionine, sodium selenite, oxidative stress

\section{INTRODUCTION}

Metabolic reactions (especially those involving oxygen) generate free radicals with the capacity to damage other molecules through oxidation (Liochev, 2013). Under normal conditions, free radical production is neutralized by the antioxidant system. However, exacerbated free radical production or defects in the antioxidant capacity result in oxidative stress (Touyz, 2004).

An adequate selenium status is essential for many physiological processes. In livestock, Se imbalances can result in altered growth, reproduction, and health (Mehdi and Dufrasne, 2016). Selenium is an indispensable component of the antioxidant system; for instance, Se can be used to synthesize glutathione peroxidase (GSH-Px; Rotruck et al., 1973). Thus, conditions that limit Se supply (e.g., decreased feed intake, feedstuff Se deficiency) or that increase Se depletion (e.g., peak lactation) might limit antioxidant capacity (Alhidary et al., 2015). Further, situations where free radical production is exacerbated (e.g., stress, disease) might increase Se requirements. In both cases, Se deficiency results in an imbalance of redox homeostasis and ultimately oxidative stress. 
Selenium content in plants is highly variable. Moreover, most of China's soil is Se deficient (Zheng et al., 1982 ) and dietary Se supplementation to livestock is frequently required. Selenium supplements can be categorized into inorganic Se [sodium selenite (SS) or sodium selenite] and organic Se (such as selenomethionine). Independent of form, the maximum supplementation dose permitted by FDA (1987) is $0.3 \mathrm{mg} / \mathrm{kg}$ of DM; therefore, in situations where Se requirements are increased, enhancing its biological availability might represent a feasible method to overcome its deficit. Previous studies showed that SS is mainly absorbed by passive diffusion in the small intestine (Weiss, 2003), although active mechanisms have been also described (Senn et al., 1992). When bound to an AA, organic Se also uses the AA transporter on the apical side of the enterocyte, a scenario that is thought to increase its absorption (Weiss, 2003).

The organic Se source hydroxy-selenomethionine (HMSeBA; commercially available as Selisseo, Adisseo Life Science Co. Ltd., Shanghai, China) is an analog of selenomethionine in which the second carbon amino group is substituted by a hydroxyl group. Since its approval by the European Commission as a feed additive in 2013 (EFSA, 2013a), results from poultry (broilers and laying hens) have shown its efficacy at muscle and egg Se enrichment (Briens et al., 2013; Jlali et al., 2013). Similarly, HMSeBA supplementation increased tissue Se deposition in growing pigs (Jlali et al., 2014). In dairy cows, a previous study from our laboratory (utilizing a nonstressed model) confirmed that HMSeBA increases antioxidant capacity parameters in blood and Se concentration in plasma and milk when compared with SS supplementation (Sun et al., 2017). Based on these results, we hypothesized that HMSeBA supplementation would decrease oxidative stress during HS. Therefore, our current study objectives were to investigate the effects of HMSeBA on Se bioavailability, antioxidant capacity, and lactation performance in lactating dairy cows during HS, a well-known inductor of oxidative stress (Halliwell et al., 1992).

\section{MATERIALS AND METHODS}

\section{Animals, Experiment Design, and Management}

All animals were handled and raised following the standards established by the Institute of Animal Science, Chinese Academy of Agricultural Sciences (Beijing, China). Eight multiparous Holstein dairy cows $(141 \pm 27$ DIM, $35.3 \pm 2.8 \mathrm{~kg}$ of milk/d, parity 2 or 3) were used and individually housed in environmental chambers at the State Key Laboratory of Animal Nutrition, Changping Experimental Base (Beijing, China).
Due to environmental chamber availability, the study was carried out in 2 replicates with 4 different cows in each replicate. After $5 \mathrm{~d}$ of acclimation to the environmental chambers, each replicate was similarly divided into 3 continuous periods: a covariate period ( $9 \mathrm{~d})$, a thermal neutral ( $\mathbf{T N})$ period $(28 \mathrm{~d})$, and a HS period (9 d). During the covariate and TN periods, all cows were housed in $\mathrm{TN}$ conditions $\left[20^{\circ} \mathrm{C}, 55 \%\right.$ humidity; temperature-humidity index $(\mathbf{T H I})=66.9]$. During the HS period, all cows were exposed to cyclical HS conditions $\left(0600-1800 \mathrm{~h}\right.$ at $36^{\circ} \mathrm{C}, 1800-0600 \mathrm{~h}$ at $32^{\circ} \mathrm{C}$, $40 \%$ humidity; THI $=82.6-84.3$ ). Cows were randomly assigned to 1 of 2 treatments: SS supplementation (0.3 $\mathrm{mg}$ of $\mathrm{Se} / \mathrm{kg}$ of $\mathrm{DM} ; \mathrm{n}=4)$ or HMSeBA supplementation $(0.3 \mathrm{mg}$ of $\mathrm{Se} / \mathrm{kg}$ of $\mathrm{DM} ; \mathrm{n}=4)$. Selenium selenite supplementation was used as a control because it is the most frequent source used in Chinese dairy rations. Cows in the SS treatment were fed SS throughout the experiment. Cows in the HMSeBA treatment were fed SS during the covariate period and HMSeBA during the TN (for prophylactic enrichment) and HS periods. The HMSeBA product was supplied by Adisseo Life Science Co. Ltd. and its Se content was $2 \%$. The SS compound was reagent grade with a $99.5 \%$ purity (Xiucang Chemical Products Co. Ltd., Henan province, China). The appropriate quantity of HMSeBA or SS was weighed, mixed with a fraction of the required amount of ground corn, and top-dressed on the TMR at each morning feeding. All cows received the same TMR formulated to meet or exceed their nutritional requirements (NRC, 2001; Table 1) of energy, protein, minerals, and vitamins. The Se concentration in the TMR before top-dressing the supplement was $0.04 \mathrm{mg} /$ $\mathrm{kg}$ of DM. During TN conditions, cows fed HMSeBA and SS received 6.0 and $5.9 \mathrm{mg}$ of $\mathrm{Se} / \mathrm{d}$, respectively, meeting NRC (2001) recommendations. During HS conditions, due to the decrease in feed intake, cows in the HMSeBA and SS treatments received 3.9 and $3.7 \mathrm{mg}$ of Se/d, respectively. Nevertheless, based on serum Se concentration $(\sim 110 \mu \mathrm{g} / \mathrm{L})$, cows were in a Se-adequate status even during HS (Gong and Xiao, 2016). Cows were fed twice daily after each milking (0730 and 1930 h). Feed refusal was removed, weighed, and recorded daily before the morning feeding for individual daily feed intake calculations. The amount of feed offered was adjusted to ensure a 5 to $10 \%$ refusal. Water was offered ad libitum, the chambers were cleaned daily, and the lighting regimen was set at $12 \mathrm{~h}$ on (0730 to $1930 \mathrm{~h}$ ) and $12 \mathrm{~h}$ off over the whole trial.

\section{Sampling and Analysis}

Temperature and relative humidity $(\mathbf{R H})$ were monitored 3 times daily (0730, 1400, and 1930 h) us- 
Table 1. Ingredients and chemical composition of the basal diet fed during the experiment ${ }^{1}$

\begin{tabular}{|c|c|}
\hline Item & Value \\
\hline \multicolumn{2}{|l|}{ Ingredient, $\%$ of $\mathrm{DM}$} \\
\hline Corn silage & 41.0 \\
\hline Alfalfa hay & 8.86 \\
\hline Oat hay & 2.95 \\
\hline Soybean meal & 8.24 \\
\hline Extruded soybean & 3.96 \\
\hline Molasses meal & 1.48 \\
\hline Steam-flaked corn ${ }^{2}$ & 14.8 \\
\hline Soybean hull & 5.64 \\
\hline Cottonseed & 3.54 \\
\hline Ground corn & 4.64 \\
\hline Milk power & 1.48 \\
\hline Fat-bergafat $^{3}$ & 0.65 \\
\hline Yeast $\mathrm{XP}^{4}$ & 0.18 \\
\hline Mildew clear ${ }^{5}$ & 0.04 \\
\hline $\mathrm{NaCl}$ & 0.36 \\
\hline Limestone & 0.44 \\
\hline $\mathrm{CaHCO}_{3}$ & 0.39 \\
\hline $\mathrm{NaHCO}_{3}$ & 0.86 \\
\hline $\mathrm{MgO}$ & 0.11 \\
\hline Premix $^{6}$ & 0.41 \\
\hline \multicolumn{2}{|c|}{ Nutrient composition, \% of DM (unless noted) } \\
\hline $\mathrm{NDF}$ & 32.8 \\
\hline $\mathrm{ADF}$ & 21.3 \\
\hline $\mathrm{CP}$ & 16.0 \\
\hline Ether extract & 5.66 \\
\hline $\mathrm{Ca}$ & 0.83 \\
\hline $\mathrm{P}$ & 0.44 \\
\hline $\mathrm{Se}(\mathrm{mg} / \mathrm{kg}$ of $\mathrm{DM})$ & 0.04 \\
\hline $\mathrm{NE}_{\mathrm{L}}(\mathrm{Mcal} / \mathrm{kg})$ & 1.70 \\
\hline
\end{tabular}

${ }^{1}$ Values represented an average of TMR samples collected and bulked during the whole experiment. Diet DM content averaged 53.36\%.

${ }^{2}$ Steam-flaked corn was processed to flake density of $0.36 \mathrm{~kg} / \mathrm{L}$.

${ }^{3} \mathrm{~A}$ saturated free fatty acid supplement (Berg + Schmidt Co., Hamburg, Germany).

${ }^{4}$ Diamond V XP yeast culture supplement (FD00365CHN-XP, Diamond V, Cedar Rapids, IA).

${ }^{5}$ Mycotoxin detoxification reagent. Main ingredients were Na-Alginate (E401), yeast (inactivated), diatomaceous earth, bentonite (Jiuzheng biology, Shanghai, China).

${ }^{6}$ Contained (per kilogram of DM) a maximum $670,000 \mathrm{IU}$ of vitamin A; 92,000 IU of vitamin D; 3,750 IU of vitamin E; $700 \mathrm{mg}$ of niacin; $2,000 \mathrm{mg}$ of $\mathrm{Cu} ; 4,000 \mathrm{mg}$ of $\mathrm{Zn} ; 330 \mathrm{mg}$ of $\mathrm{Mn} ; 65 \mathrm{mg}$ of I; $37 \mathrm{mg}$ of Co.

ing recorders (Beijing Yaguang Equipment Co. Ltd., Beijing, China) that were calibrated at the beginning of the trial and weekly thereafter. The recorder was placed in the center of the chamber's sidewall, about $1.5 \mathrm{~m}$ from the ground. Temperature-humidity index was calculated as THI $=\left(0.8 \times \mathrm{T}_{\mathrm{a}}\right)+[(\mathrm{RH} / 100)$ $\left.\times\left(\mathrm{T}_{\mathrm{a}}-14.3\right)\right]+46.4$ (adapted from Thom, 1959), where $\mathrm{T}_{\mathrm{a}}$ is the ambient temperature (in ${ }^{\circ} \mathrm{C}$ ) and $\mathrm{RH}$ is expressed as a percentage. Body temperature indices were recorded 3 times daily (0730, 1400, and $1930 \mathrm{~h}$ ). Rectal temperature (RT) was measured using a glass mercury thermometer, and respiration rate $(\mathbf{R R})$ was determined by counting flank movements for $1 \mathrm{~min}$.

Samples from the offered TMR and orts were collected from each cow every other day during the covariate and HS periods, as well as the last $2 \mathrm{~d}$ of every week in the TN period. All samples were dried at $65^{\circ} \mathrm{C}$ for $48 \mathrm{~h}$, ground using a fodder grinder, and passed through a 1-mm screen for further analysis. Dry matter content was determined by oven drying to a constant weight $\left(105^{\circ} \mathrm{C}, 4 \mathrm{~h}\right)$. An average DM content was determined per cow and period and used to calculate the individual daily DMI. Samples from all the periods and both treatments were mixed for nutrient composition analysis. The NDF was determined following the method described by Van Soest et al. (1991) using $\alpha$-amylase and sodium sulfide. The ADF and CP were analyzed according to methods $973.18 \mathrm{C}$ (AOAC, 1990) and 976.05 (AOAC International, 2000), respectively. Ether extract content was analyzed as described by Thiex et al. (2003) using a Soxtec 2050 system (Foss Analytical A/S, Hillerød, Denmark). Calcium and phosphorus contents were determined by atomic absorption spectroscopy (method 985.35; AOAC, 1990) and spectrophotometry (method 986.24; AOAC, 1990), respectively.

For each cow, mixed milk samples from the morning and afternoon milkings were collected daily during the covariate and HS periods and the last $2 \mathrm{~d}$ of every week in the TN period. A 50-mL subsample had a preservative (Bronopol tablet, D\&F Control System, San Ramon, CA) added for milk composition analysis. Protein, fat, lactose, and TS content were analyzed by mid-infrared procedures using a MilkoScan Minor machine (MilkoScan Type 78110; Foss Electric, Hillerød, Denmark). Somatic cell counts were analyzed using a Fossomatic 5000 analyzer (Foss Food Technology Corp., Eden Prairie, MN). An extra 10-mL milk subsample was frozen at $-20^{\circ} \mathrm{C}$ for total Se concentration analysis.

Blood samples were collected on d 1, 2, 3, 5, 7, and 9 during the covariate and HS periods and the last $2 \mathrm{~d}$ of every week in the TN period $2 \mathrm{~h}$ after the morning feeding via coccygeal venipuncture. At each collection, a duplicate 10-mL blood sample was obtained in serum separator tubes (BD Biosciences, Franklin Lakes, NJ) without additives, allowed to clot, centrifuged at 3,000 $\times g$ for 15 min at $4^{\circ} \mathrm{C}$ to obtain serum, and then frozen at $-20^{\circ} \mathrm{C}$ for subsequent analysis. Alanine aminotransferase (ALT), aspartate aminotransferase (AST), alkaline phosphatase (ALP), creatine kinase (CK), cholinesterase, creatinine, urea, uric acid, and glucose were measured with an automatic analyzer (Mindray 420, Mindray Bio-Medical Electronics Co. Ltd., Shenzhen, China). The intra- and interassay coefficients of variation for ALT, AST, ALP, CK, cholinesterase, creatinine, urea, uric acid, and glucose were 1.9 and $2.9 \%, 2.5$ and $3.7 \%, 3.5$ and $4.0 \%, 2.6$ and $3.4 \%, 1.3$ and $1.9 \%, 1.9$ and $2.1 \%, 1.6$ and $1.8 \%, 1.9$ and $2.0 \%$, and 1.4 and $1.9 \%$; respectively. One ALT active unit is 
defined as the amount of enzyme producing $2.5 \mu \mathrm{g}$ of pyruvic acid from alanine and $\alpha$-ketoglutaric acid at $37^{\circ} \mathrm{C}$ for $30 \mathrm{~min}$. One Karman unit of AST is defined as the amount of enzyme decreasing absorbance by 0.001 due to oxidation of NADPH to $\mathrm{NAD}^{+}$at $25^{\circ} \mathrm{C}$ in $1 \mathrm{~min}$ and $1 \mathrm{~mL}$ of serum (1 Karman unit is equal to 0.48 $\mathrm{U})$. One King unit of ALP is defined as the amount of enzyme reacting with substrate to produce $1 \mathrm{mg}$ of phenol at $37^{\circ} \mathrm{C}$ in $15 \mathrm{~min}$ and $100 \mathrm{~mL}$ serum (1 King unit is equal to $7.14 \mathrm{U}$ ). One unit of $\mathrm{CK}$ is defined as the amount of enzyme producing $1 \mathrm{nmol}$ of NADPH at $37^{\circ} \mathrm{C}$ in $1 \mathrm{~min}$ and $1 \mathrm{~L}$ of serum. Free fatty acids concentration, GSH-Px and superoxide dismutase (SOD) activity, total antioxidant capacity (T-AOC), and malondialdehyde (MDA), $\mathrm{H}_{2} \mathrm{O}_{2}$, and nitric oxide (NO) content were determined using commercial detection kits (A042, A005, A001-3, A015, A003-1, A064, A012; Nanjing JianCheng Bioengineering Institute, Nanjing, China). The intra- and interassay coefficients of variation were 2.4 and $5.6 \%, 3.1$ and $4.3 \%, 1.7$ and $3.5 \%$, 3.2 and $6.8 \%, 3.5$ and $4.1 \%, 1.2$ and $2.4 \%$, and 2.0 and $5.2 \%$ for free fatty acids, GSH-Px, SOD, T-AOC, MDA, $\mathrm{H}_{2} \mathrm{O}_{2}$, and NO, respectively. One unit of GSH-Px is defined as the amount of enzyme reducing $1 \mu \mathrm{mol}$ of GSH at $37^{\circ} \mathrm{C}$ in $5 \mathrm{~min}$ and $0.1 \mathrm{~mL}$ of serum. One unit of SOD is defined as the amount of enzyme to inhibit $50 \%$ of nitroblue tetrazolium at $37^{\circ} \mathrm{C}$ in $20 \mathrm{~min}$ and $20 \mu \mathrm{L}$ of serum. One unit of T-AOC is defined as the amount that produces an increase of absorbance by 0.01 due to the reduction of $\mathrm{Fe}^{3+}$ to $\mathrm{Fe}^{2+}$ at $37^{\circ} \mathrm{C}$ in 1 min and 0.1 $\mathrm{mL}$ of serum.

Mixed TMR samples per treatment and individual milk and serum samples in the covariate and HS periods were used to determine the total Se concentration according to the methods of the National Standard of the People's Republic of China: National Food Safety Standard-Maximum residue limits for pesticides in food (National Standard of the People's Republic of China, 2016). Briefly, $0.2 \mathrm{~g}$ of TMR samples or $1 \mathrm{~mL}$ of milk or serum were accurately measured, digested in $5 \mathrm{~mL}$ of hydrochloric acid, heated at $100^{\circ} \mathrm{C}$ for $30 \mathrm{~min}$ in a heating block, and then diluted with water to a 20 $\mathrm{mL}$ final volume. The mixed solution was then used to determine total Se concentration utilizing inductively coupled plasma mass spectrometry (ICP-MS/MS, Agilent 8800, Agilent, Santa Clara, CA).

\section{Statistical Analysis}

All data were statistically analyzed using SAS software (version 9.4, SAS Institute Inc., Cary, NC), utilizing 2 different models. The first model aimed to determine the effects of HS on RT, RR, DMI, milk yield, and serum $\mathrm{H}_{2} \mathrm{O}_{2}$ and $\mathrm{NO}$ content by comparing the TN and HS periods. For this purpose, one-way ANOVA was performed utilizing the GLIMMIX procedure of SAS. The second model investigated the effects of dietary treatment and time on body temperature indices and milk and blood parameters during the HS period. A repeated measures analysis was conducted using PROC MIXED of SAS and compound symmetry to describe the covariance structure. The model included treatment, replicate, day within the HS period, and their respective interactions as fixed effects and cow within treatment $\times$ replicate as a random effect and as the subject for the repeated measures. For each cow and variable, a mean value was calculated for the covariate period and used as a covariate. The model used to analyze the effect of treatment on the parameter of interest over time taking into account intracow variability was

$$
\begin{gathered}
\mathrm{Y}_{\mathrm{ijkl}}=\mu+\mathrm{T}_{\mathrm{i}}+\mathrm{P}_{\mathrm{j}}+\mathrm{TP}_{\mathrm{ij}}+\mathrm{bX}_{\mathrm{jk}}+\mathrm{C}(\mathrm{TP})_{\mathrm{ijk}}+\mathrm{D}_{\mathrm{l}} \\
+\mathrm{DT}_{\mathrm{il}}+\mathrm{DP}_{\mathrm{jl}}+\mathrm{DTP}_{\mathrm{ijl}}+\varepsilon_{\mathrm{ijk} \mathrm{k}},
\end{gathered}
$$

where $Y_{\mathrm{ijkl}}=$ dependent variable measured on day $\mathrm{l}$ of the HS period in replicate $\mathrm{j}$ on the kth cow assigned to the ith treatment; $\mu=$ overall mean; $T_{i}=$ effect of treatment; $\mathrm{P}_{\mathrm{j}}=$ effect of replicate; $\mathrm{TP}_{\mathrm{ij}}=$ effect of treatment $\times$ replicate; $\mathrm{bX}_{\mathrm{jk}}=$ effect of covariate; $\mathrm{C}(\mathrm{TP})_{\mathrm{ijk}}=$ random effect of cow within treatment $\times$ replicate; $D_{1}$ $=$ effect of day within HS period; $\mathrm{DT}_{\mathrm{il}}=$ effect of day $\times$ treatment; $\mathrm{DP}_{\mathrm{lj}}=$ effect of day $\times$ replicate; $\mathrm{DTP}_{\mathrm{ijl}}$ $=$ effect of treatment $\times$ day $\times$ replicate; and $\varepsilon_{\mathrm{ikjl}}=$ random error. Data are reported as least squares means and considered significant if $P<0.05$ and a tendency if $0.05 \leq P<0.10$.

\section{RESULTS}

As expected, THI during HS was higher than in the TN period $(P<0.01)$. Heat stress increased RT and RR $\left(1.2^{\circ} \mathrm{C}, P<0.01\right.$ and 2.08 -fold, $P<0.01$, respectively). Dry matter intake and milk yield were decreased (34.9\%, $P<0.01$ and $31.8 \%, P=0.02$, respectively), and serum $\mathrm{H}_{2} \mathrm{O}_{2}$ and $\mathrm{NO}$ concentrations were increased (31.7\%, $P<0.05$ and $186.1 \%, P<0.01$, respectively) during HS compared with the TN period (Table 2).

\section{Se Concentration in Serum and Milk}

The effects of dietary Se source on Se concentrations in serum and milk are presented in Table 3. Selenium concentrations in serum and milk were higher in HMSeBA-fed cows compared with SS-fed controls $(25.5 \%, P$ $=0.03$ and $71.2 \%, P<0.01$, respectively). As a result, the Se milk-to-serum concentration ratio was also increased by HMSeBA treatment $(35.5 \%, P<0.01)$. 
Table 2. The estimated values of relative parameters under thermal neutral (TN) and heat stress (HS) conditions $^{1}$

\begin{tabular}{lccrr}
\hline Item & TN $(\mathrm{n}=8)$ & HS $(\mathrm{n}=8)$ & SEM $^{2}$ & $P$-value \\
\hline $\mathrm{THI}^{3}$ & 66.9 & 83.2 & 1.0 & $<0.01$ \\
$\mathrm{RT}^{5}{ }^{\circ}{ }^{\circ} \mathrm{C}$ & 38.5 & 39.7 & 0.1 & $<0.01$ \\
$\mathrm{RR},{ }^{6} \mathrm{bpm}$ & 34.6 & 71.9 & 1.6 & $<0.01$ \\
DMI, kg/d & 17.2 & 11.2 & 0.3 & $<0.01$ \\
Milk yield, $\mathrm{kg} / \mathrm{d}$ & 31.1 & 21.2 & 0.7 & 0.02 \\
Hydrogen peroxide, $\mathrm{mmol} / \mathrm{L}$ & 30.0 & 39.5 & 0.7 & $<0.05$ \\
Nitric oxide, $\mu \mathrm{mol} / \mathrm{mL}$ & 10.1 & 28.9 & 1.3 & $<0.01$ \\
\hline
\end{tabular}

${ }^{1}$ The data used for TN period was the last $2 \mathrm{~d}$ of every week.

${ }^{2} \mathrm{SEM}$ for comparison between the 2 periods (TN vs. HS) within all treatments.

${ }^{3}$ The comparison of the 2 periods (TN vs. HS) within all treatments.

${ }^{4}$ Temperature-humidity index.

${ }^{5}$ Rectal temperature.

${ }^{6}$ Respiratory rate; bpm = beats per minute.

\section{Antioxidant Parameters in Serum}

The effects of Se source on serum antioxidant parameters are presented in Table 4 and Figure 1. We noted a treatment by day interaction $(P<0.01)$ and a tendency for an interaction $(P=0.07)$ in serum GSH-Px activity and MDA concentration, respectively; GSH-Px activity did not change in HMSeBA-supplemented cows as HS progressed but it decreased in SSfed controls, whereas MDA concentration decreased in HMSeBA-supplemented cows but it did not change in SS-supplemented cows (Figure 1). Selenium source had no effect on SOD activity $(P=0.11)$, but HMSeBA supplementation increased T-AOC capacity $(20.0 \%, P$ $=0.04)$ and decreased $\mathrm{H}_{2} \mathrm{O}_{2}$ and $\mathrm{NO}$ concentrations compared with SS $(18.5 \%, P<0.05$ and $22.9 \%, P=$ 0.04 , respectively).

\section{Body Temperature Indices and Performance}

The effects of Se source on RT, RR, DMI, milk production, milk composition, and SCS are presented in Table 5. Body temperature indices and DMI were not affected by Se source $(P>0.10)$, but milk yield tended to be higher in HMSeBA-supplemented cows than in SS-fed controls $(9.3 \%, P=0.08)$. We found no treatment effects on 4\% FCM, ECM, feed efficiency, milk SCS, milk composition, or milk component yields $(P>0.10)$, except for milk fat percentage, which was decreased by HMSeBA supplementation $(18.1 \%, P=$ $0.04)$.

\section{Biochemical Parameters in Serum}

The effects of dietary Se source on biochemical parameters in serum are presented in Table 6. Cows supplemented with HMSeBA had lower ALT activity than SS-fed cows $(19.7 \%, P=0.04)$. We observed no treatment effects on any other biochemical parameter $(P>0.05)$.

\section{DISCUSSION}

Dairy cows encounter a variety of situations characterized by increased free radical production (e.g., calving, activated immune response, and so on), which are counteracted by the antioxidant system to maintain homeostasis. However, when free radical production is exacerbated or the antioxidant capacity is defective, cows might experience oxidative stress. Free radical accumulation results in oxidative damage at the molecular level (Dargel, 1992), which ultimately might alter

Table 3. Effects of selenium source on selenium concentration in serum and milk during heat stress period

\begin{tabular}{|c|c|c|c|c|c|c|}
\hline \multirow[b]{2}{*}{ Item } & \multicolumn{2}{|c|}{ Treatment $(\text { Trt })^{1}$} & \multirow[b]{2}{*}{ SEM } & \multicolumn{3}{|c|}{$P$-value } \\
\hline & $\mathrm{SS}-0.3(\mathrm{n}=4)$ & HMSeBA-0.3 $(\mathrm{n}=4)$ & & Trt & Day & Trt $\times$ day \\
\hline Serum total Se, $\mu \mathrm{g} / \mathrm{L}$ & 102 & 128 & 2 & 0.03 & 0.07 & 0.95 \\
\hline Milk total Se, $\mu \mathrm{g} / \mathrm{L}$ & 29.9 & 51.2 & 1.2 & $<0.01$ & 0.75 & 0.79 \\
\hline (Milk/serum of total Se), \% ratio & 29.6 & 40.1 & 1.6 & $<0.01$ & $<0.01$ & 0.16 \\
\hline
\end{tabular}

${ }^{1} \mathrm{SS}-0.3=0.3 \mathrm{mg}$ of $\mathrm{Se} / \mathrm{kg}$ of DM sodium selenite supplementation; HMSeBA-0.3 = $0.3 \mathrm{mg}$ of Se/kg of DM hydroxy-selenomethionine supplementation. 
Table 4. Effects of selenium source on blood oxidation parameters under heat stress period

\begin{tabular}{|c|c|c|c|c|c|c|}
\hline Item & \multicolumn{2}{|c|}{ Treatment $(\text { Trt })^{1}$} & SEM & \multicolumn{3}{|c|}{$P$-value } \\
\hline Glutathione peroxidase, $\mathrm{U} / \mathrm{mL}$ & 97 & 107 & 3 & 0.41 & $<0.01$ & $<0.01$ \\
\hline Total antioxidant capacity, $\mathrm{U} / \mathrm{mL}$ & 2.0 & 2.4 & 0.1 & 0.04 & 0.77 & 0.95 \\
\hline Malondialdehyde, $\mathrm{nmol} / \mathrm{mL}$ & 7.1 & 6.2 & 0.2 & 0.03 & 0.09 & 0.07 \\
\hline Hydrogen peroxide, $\mathrm{mmol} / \mathrm{L}$ & 43.7 & 35.6 & 0.8 & $<0.05$ & 0.86 & 0.56 \\
\hline
\end{tabular}

${ }^{1} \mathrm{SS}-0.3=0.3 \mathrm{mg}$ of $\mathrm{Se} / \mathrm{kg}$ of DM sodium selenite supplementation; HMSeBA-0.3 $=0.3 \mathrm{mg}$ of Se $/ \mathrm{kg}$ of DM hydroxy-selenomethionine supplementation.

physiological functions and affect economically important phenotypes (Sharma et al., 2011). Selenium is an essential component of the antioxidant system, and its dietary supplementation enhances antioxidant capacity (Skřivan et al., 2012). However, when feedstuffs are Se deficient or Se requirements are transiently increased, supplemental Se (even at the maximum regulatory allowance) might be insufficient. Utilizing organic minerals is a feasible strategy to improve their bioavailability, as feeding HMSeBA improved Se concentration in blood and milk in lactating dairy cows (Sun et al., 2017) and has been shown to enrich other tissues in different species (Briens et al., 2013; Jlali et al., 2013; Jlali et al., 2014). Thus, we hypothesized the beneficial effects of HMSeBA could be further enhanced during an oxidative stress inducing condition, such as HS (Aréchiga et al., 1994). In the current study, cows endured a high level of HS (THI > 78; Armstrong, 1994); consequently, body temperature indices were substantially increased and DMI and milk yield decreased. Further, hyperthermia elevated blood $\mathrm{H}_{2} \mathrm{O}_{2}$ and $\mathrm{NO}$ concentrations, as expected (Grant and Loake, 2000; Polle, 2001); thus, we effectively created a HS-inducing oxidative stress model.

Selenium content in blood is an appropriate indicator of Se status in cows (Burk and Hill, 2009), and concentrations in the 80 to $160 \mu \mathrm{g} / \mathrm{L}$ range have been reported as adequate (Dargatz and Ross, 1996). In the current experiment both treatments were within normal limits, but supplementing HMSeBA increased Se concentration in blood compared with SS supplementation during HS (127.9 vs. $101.9 \mu \mathrm{g} / \mathrm{L})$. As with other organic minerals, increased blood content might be partially the result of increased absorption at the intestinal level, as they might be able to be absorbed via their AA carrier (Sauer et al., 2017). For instance, inorganic Se is mainly assimilated by passive diffusion, but it can also use an active GSH-dependent transporter (Senn et al., 1992), whereas selenomethionine (an HMSeBA analog) also uses the methionine transport system (Weiss, 2003). Further, organic Se has higher biological activity than inorganic Se (Ortman and Pehrson, 1999). Blood selenium content is positively correlated with milk Se concentrations (Ivancic and Weiss, 2001).
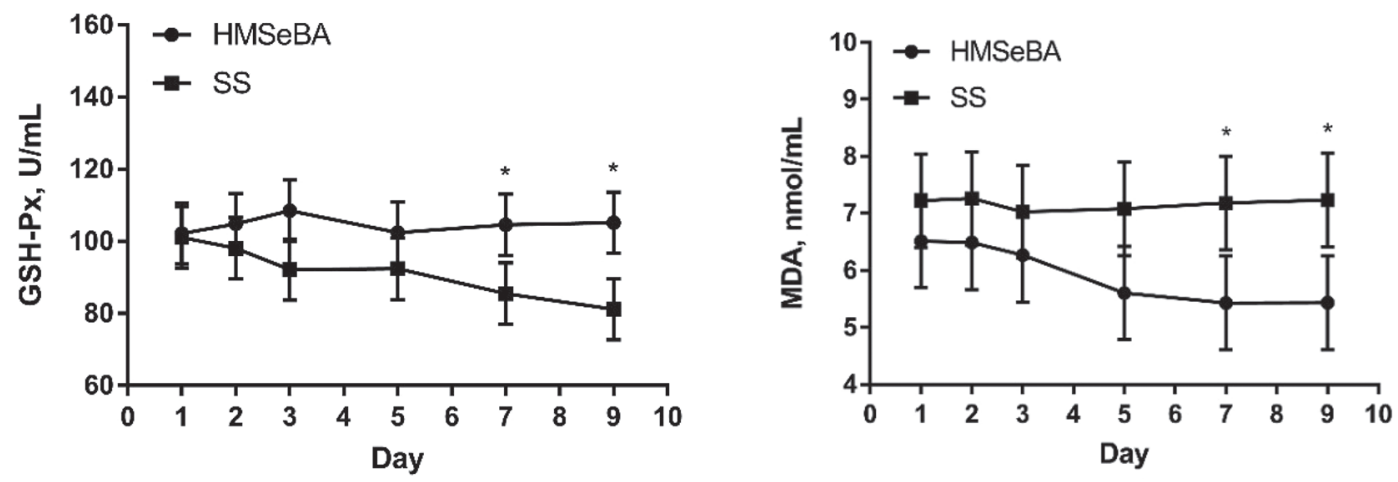

Figure 1. Effects of Se source on glutathione peroxidase and malondialdehyde in lactating Holstein cows under heat stress-induced oxidative stress. The lines with circles represent $0.3 \mathrm{mg}$ of Se $/ \mathrm{kg}$ of DM hydroxy-selenomethionine supplementation (HMSeBA), and lines with squares represent $0.3 \mathrm{mg}$ of $\mathrm{Se} / \mathrm{kg}$ of DM sodium selenite supplementation. Asterisks represent a significant difference $(P<0.05)$ between treatments. Error bars represent the SEM. 
Table 5. Effects of selenium source on body temperature indices, DMI, milk production, and milk composition during the heat stress period

\begin{tabular}{|c|c|c|c|c|c|c|}
\hline Item & \multicolumn{2}{|c|}{ Treatment $(\text { Trt })^{1}$} & SEM & \multicolumn{3}{|c|}{$P$-value } \\
\hline $\mathrm{RT},{ }^{2}{ }^{\circ} \mathrm{C}$ & 39.7 & 39.6 & 0.1 & 0.96 & 0.56 & 0.28 \\
\hline DMI, $\mathrm{kg} / \mathrm{d}$ & 10.9 & 11.6 & 0.4 & 0.57 & 0.13 & 0.78 \\
\hline Milk yield, $\mathrm{kg} / \mathrm{d}$ & 19.3 & 21.1 & 0.2 & 0.08 & 0.02 & 0.19 \\
\hline $4 \% \mathrm{FCM}^{4}$ & 19.6 & 20.2 & 0.5 & 0.84 & 0.03 & 1.00 \\
\hline Protein yield, $\mathrm{kg} / \mathrm{d}$ & 0.65 & 0.66 & 0.02 & 0.86 & $<0.01$ & 0.84 \\
\hline Fat yield, $\mathrm{kg} / \mathrm{d}$ & 0.83 & 0.75 & 0.02 & 0.18 & 0.17 & 1.00 \\
\hline Lactose yield, $\mathrm{kg} / \mathrm{d}$ & 0.95 & 1.00 & 0.03 & 0.67 & $<0.01$ & 0.98 \\
\hline Protein, \% & 3.28 & 3.20 & 0.03 & 0.46 & 0.33 & 0.40 \\
\hline Fat, $\%$ & 4.30 & 3.52 & 0.34 & 0.04 & 0.66 & 0.94 \\
\hline Lactose, \% & 4.92 & 4.96 & 0.02 & 0.51 & 0.91 & 0.70 \\
\hline TS, $\%$ & 13.1 & 12.5 & 0.1 & 0.44 & 0.41 & 0.95 \\
\hline
\end{tabular}

${ }^{1} \mathrm{SS}-0.3=0.3 \mathrm{mg}$ of $\mathrm{Se} / \mathrm{kg}$ of DM sodium selenite supplementation; HMSeBA-0.3 $=0.3 \mathrm{mg}$ of Se/kg of DM hydroxy-selenomethionine supplementation.

${ }^{2}$ Rectal temperature.

${ }^{3}$ Respiratory rate; bpm $=$ beats per minute.

${ }^{4} 4 \% \mathrm{FCM}=0.4(\mathrm{~kg}$ of milk $)+15.0(\mathrm{~kg}$ of fat $)$.

${ }^{5} \mathrm{ECM}=0.327(\mathrm{~kg}$ of milk $)+12.95(\mathrm{~kg}$ of fat $)+7.20(\mathrm{~kg}$ of protein $)$

${ }^{6}$ Efficiency $=4 \%$ FCM $/$ DMI.

${ }^{7} \mathrm{SCS}=\log _{2}[\mathrm{SCC}($ cells per $\mathrm{mL}) / 100,000]+3$.

In agreement, milk Se concentration was $71 \%$ higher in HMSeBA-fed cows compared with controls. Previous ruminant reports have similarly demonstrated that Se organic sources outperformed SS in terms of bioavailability at different ages and physiological status (Weiss, 2003; Ceballos et al., 2009). In this regard, HMSeBA supplementation increases eggs and muscle Se enrichment in poultry (Briens et al., 2013; Jlali et al., 2013) and pigs (Jlali et al., 2014).

Organic Se supplementation ameliorated the HSinduced imbalances in the oxidant and antioxidant systems. Specifically, feeding HMSeBA decreased blood free radical $\left(\mathrm{H}_{2} \mathrm{O}_{2}, \mathrm{NO}\right)$ concentrations during HS. A certain amount of free radicals is essential to the body, for example, to mount an adequate immune response (Riley, 1994); however, excessive free radical production, which can cause DNA damage, protein crosslinking, and lipid peroxidation, ultimately leads to oxidative stress (Dargel, 1992). In the current study, cows supplemented with HMSeBA had lower MDA blood content (indicative of lipid peroxidation; Gaweł et al., 2004) than SS-fed cows, presumably due to the reduction in reactive species. An excessive free radical production is counteracted by the antioxidant defense

Table 6. Effects of selenium source on blood biochemical parameters under heat stress period

\begin{tabular}{|c|c|c|c|c|c|c|}
\hline Item & \multicolumn{2}{|c|}{ Treatment $(\mathrm{Trt})^{1}$} & SEM & \multicolumn{3}{|c|}{$P$-value } \\
\hline Alanine aminotransferase, U/L & 24.4 & 19.6 & 0.5 & 0.04 & $<0.01$ & 0.80 \\
\hline Alkaline phosphatase, U/L & 40.4 & 42.7 & 1.5 & 0.54 & 0.01 & 0.40 \\
\hline Creatine kinase, $\mathrm{U} / \mathrm{L}$ & 144 & 131 & 2 & 0.11 & 0.49 & 0.17 \\
\hline Creatinine, $\mu \mathrm{mol} / \mathrm{L}$ & 88.8 & 81.3 & 1.6 & 0.32 & $<0.01$ & 0.67 \\
\hline Glucose, $\mathrm{mmol} / \mathrm{L}$ & 3.0 & 3.2 & 0.1 & 0.16 & $<0.01$ & 0.70 \\
\hline Free fatty acids, umol/L & 613 & 626 & 40 & 0.88 & 0.10 & 0.15 \\
\hline
\end{tabular}

${ }^{1} \mathrm{SS}-0.3=0.3 \mathrm{mg}$ of $\mathrm{Se} / \mathrm{kg}$ of DM sodium selenite supplementation; HMSeBA-0.3 = $0.3 \mathrm{mg}$ of Se/kg of DM hydroxy-selenomethionine supplementation. 
system, within which Se plays a major role as constitutive part of its main enzymes. Total antioxidant capacity was increased in HMSeBA-fed cows compared with SS controls. This might be the result of increasing Se bioavailability by feeding its organic form, which makes this mineral available for the synthesis and action of the antioxidant enzymes. Accordingly, as HS progressed, serum GSH-Px activity was maintained in HMSeBAsupplemented cows whereas it decreased in controls. As a result, serum GSH-Px activity in HMSeBA fed cows was significantly higher than the SS treatment on $\mathrm{d} 7$ and 9 of environmental exposure. This is in agreement with our previous results in lactating cows in TN conditions (Sun et al., 2017) and in heat-stressed broilers (Mahmoud and Edens, 2003). In contrast, SOD activity (which catalyzes the transformation of superoxide anions into $\mathrm{H}_{2} \mathrm{O}_{2}$ in the mitochondria; Halliwell and Gutteridge, 2007) did not differ between treatments.

Feeding HMSeBA tended to prevent the negative effects of HS on milk yield without affecting DMI. Further, increased milk production in HMSeBA-supplemented cows was not associated with changes in blood metabolic, hepatic, and renal parameters. We acknowledge that the small sample size and experimental length prevent us from appropriately evaluating the effects of HMSeBA supplementation on performance. However, counteracting an increase in free radical production is an energetically costly process, which might partially explain the reduction in milk production experienced by HS cows. Both eliciting an antioxidant response and repairing free radical-induced damages require energy (Pedernera et al., 2010). Increasing Se bioavailability enhances antioxidant capacity and reduces free radical consequences. Thus, we speculated that the improvement in milk production in the HMSeBA-supplemented cows might be the result of increased energy availability. This is not reflected in the milk energy content of the current study (i.e., we found no significant differences in $4 \% \mathrm{FCM}$ and ECM, although they were numerically increased), and additional studies aimed to specifically evaluate performance (with a larger sample sizes) should be performed for clarification. Additional explanations for the milk yield increase might include reduced free radical-induced damage within the mammary gland (Miller et al., 1993), which would likely enhance milk synthesis. Within milk composition, only fat content was affected by Se source, as HMSeBA-fed cows had a lower milk fat percentage compared with SS controls. This agrees with Fraser et al. (1987), who showed a negative relationship between blood Se and milk fat content when Se supplementation was first introduced in the herd. Although the mechanism is not entirely clear, increased Se might upregulate oxidative reactions within the tricarboxylic cycle and fatty acid metabolism, which might explain the inverse relationship (Wang et al., 2009).

A limitation to the current study is the lack of measurements of blood parameters during the TN period, preventing us from differentiating between the overall effects of HMSeBA supplementation (independent of environmental exposure) and those specific to HS conditions. However, certain parameters suggest that the results are due to the enhanced beneficial effects of HMSeBA during hyperthermia. Specifically, the treatment by day interactions on GSH-Px and MDA concentration give an idea of the antioxidant response during HS being modulated by Se source.

\section{CONCLUSIONS}

Results from this study showed that supplemental HMSeBA improved milk yield and T-AOC and decreased MDA, $\mathrm{H}_{2} \mathrm{O}_{2}$, and $\mathrm{NO}$ content of dairy cows enduring HS-induced oxidative stress. Therefore, during HS, HMSeBA supplementation may be an effective dietary strategy to minimize the negative effects of environmental hyperthermia.

\section{ACKNOWLEDGMENTS}

We gratefully acknowledge Cary Crow at University of Manitoba (Winnipeg, Canada) for his contribution to the statistical analysis of the paper. This research was financially supported by the National Program for Support of Top-notch Professionals (China), the Agricultural Science and Technology Innovation Programs (ASTIPIAS07; CAAS-XTCX2016011-01; China), Beijing Dairy Industry Innovation Team (BJDIIT; China), and the Ministry of Science and Technology the Ministry of Science and Technology Program (2018YFD0501602).

\section{REFERENCES}

Alhidary, I. A., S. Shini, R. A. Al Jassim, A. M. Abudabos, and J. B. Gaughan. 2015. Effects of selenium and vitamin E on performance, physiological response, and selenium balance in heat-stressed sheep. J. Anim. Sci. 93:576-588.

AOAC (Association of Official Analytical Chemists). 1990. Official Methods of Analysis. 15th ed. AOAC, Arlington, VA.

AOAC International. 2000. Official Methods of Analysis. 17th ed. AOAC International, Gaithersburg, MD.

Aréchiga, C. F., A. D. Ealy, and P. J. Hansen. 1994. Efficacy of vitamin $\mathrm{E}$ and glutathione for thermoprotection of murine morulae. Theriogenology 41:1545-1553.

Armstrong, D. V. 1994. Heat stress interaction with shade and cooling. J. Dairy Sci. 77:2044-2050.

Briens, M., Y. Mercier, F. Rouffineau, V. Vacchina, and P. A. Geraert. 2013. Comparative study of a new organic selenium source v. seleno-yeast and mineral selenium sources on muscle selenium enrichment and selenium digestibility in broiler chickens. Br. J. Nutr. 110:617-624. 
Burk, R. F., and K. E. Hill. 2009. Selenoprotein P-expression, functions, and roles in mammals. Biochim. Biophys. Acta 1790:14411447.

Ceballos, A., J. Sánchez, H. Stryhn, J. B. Montgomery, H. W. Barkema, and J. J. Wichtel. 2009. Meta-analysis of the effect of oral selenium supplementation on milk selenium concentration in cattle. J. Dairy Sci. 92:324-342.

Dargatz, D. A., and P. F. Ross. 1996. Blood selenium concentrations in cows and heifers on 253 cow-calf operations in 18 states. J. Anim. Sci. 74:2891-2895.

Dargel, R. 1992. Lipid peroxidation-a common pathogenetic mechanism? Exp. Toxicol. Pathol. 44:169-181.

EFSA. 2013a. Scientific opinion on safety and efficacy of hydroxyanalogue of selenomethionine as feed additive for all species. EFSA J. 11:3046.

FDA. 1987. Food additives permitted in feed and drinking water of animals. Selenium. Fed. Regist. 52:10887-10888.

Fraser, A. J., T. J. Ryan, R. Sproule, R. G. Clark, D. Anderson, and E. O. Pederson. 1987. The effect of selenium supplementation on milk production in dairy cattle. Pages $61-64$ in Proc. N. Z. Soc. Anim. Prod. Vol. 47.

Gaweł, S., M. Wardas, E. Niedworok, and P. Wardas. 2004. [Malondialdehyde (MDA) as a lipid peroxidation marker]. Wiad. Lek. 57:453-455. (In Polish).

Gong, J., and M. Xiao. 2016. Selenium and antioxidant status in dairy cows at different stages of lactation. Biol. Trace Elem. Res. 171:89-93.

Grant, J. J., and G. J. Loake. 2000. Role of reactive oxygen intermediates and cognate redox signaling in disease resistance. Plant Physiol. 124:21-29.

Halliwell, B., and J. Gutteridge. 2007. Free Radical in Biology and Medicine.Press, Oxford University Press, Oxford, UK.

Halliwell, B., J. M. Gutteridge, and C. E. Cross. 1992. Free radicals, antioxidants, and human disease: where are we now? J. Lab. Clin. Med. 119:598-620.

Ivancic, J., and W. P. Weiss. 2001. Effect of dietary sulfur and selenium concentrations on selenium balance of lactating Holstein cows. J. Dairy Sci. 84:225-232.

Jlali, M., M. Briens, F. Rouffineau, P. A. Geraert, and Y. Mercier. 2014. Evaluation of the efficacy of 2-hydroxy-4-methylselenobutanoic acid on growth performance and tissue selenium retention in growing pigs. J. Anim. Sci. 92:182-188.

Jlali, M., M. Briens, F. Rouffineau, F. Mercerand, P. A. Geraert, and Y. Mercier. 2013. Effect of 2-hydroxy-4-methylselenobutanoic acid as a dietary selenium supplement to improve the selenium concentration of table eggs. J. Anim. Sci. 91:1745-1752.

Liochev, S. I. 2013. Reactive oxygen species and the free radical theory of aging. Free Radic. Biol. Med. 60:1-4.

Mahmoud, K. Z., and F. W. Edens. 2003. Influence of selenium sources on age-related and mild heat stress-related changes of blood and liver glutathione redox cycle in broiler chickens (Gallus domesticus). Comp. Biochem. Physiol. B Biochem. Mol. Biol. 136:921-934.

Mehdi, Y., and I. Dufrasne. 2016. Selenium in cattle: A review. Molecules 21:545.

Miller, J. K., E. Brzezinska-Slebodzinska, and F. C. Madsen. 1993. Oxidative stress, antioxidants, and animal function. J. Dairy Sci. $76: 2812-2823$.

National Standard of the People's Republic of China. 2016. National Food Safety Standard-Maximum residue limits for pesticides in food/GB5009.268-2016. Stands Press of China, Beijing, China.
NRC. 2001. Nutrient Requirements of Dairy Cattle. 7th rev. ed. Natl. Acad. Press, Washington, DC.

Ortman, K., and B. Pehrson. 1999. Effect of selenate as a feed supplement to dairy cows in comparison to selenite and selenium yeast. J. Anim. Sci. 77:3365-3370.

Pedernera, M., P. Celi, S. C. García, H. E. Salvin, I. Barchia, and W. J. Fulkerson. 2010. Effect of diet, energy balance and milk production on oxidative stress in early-lactating dairy cows grazing pasture. Vet. J. 186:352-357.

Polle, A. 2001. Dissecting the superoxide dismutase-ascorbate-glutathione-pathway in chloroplasts by metabolic modeling. Computer simulations as a step towards flux analysis. Plant Physiol. 126:445-462.

Riley, P. A. 1994. Free radicals in biology: oxidative stress and the effects of ionizing radiation. Int. J. Radiat. Biol. 65:27.

Rotruck, J. T., A. L. Pope, H. E. Ganther, A. B. Swanson, D. G. Hafeman, and W. G. Hoekstra. 1973. Selenium: Biochemical role as a component of glutathione peroxidase. Science 179:588-590.

Sauer, A. K., S. Pfaender, S. Hagmeyer, L. Tarana, A. K. Mattes, F. Briel, S. Küry, T. M. Boeckers, and A. M. Grabrucker. 2017. Characterization of zinc amino acid complexes for zinc delivery in vitro using Caco-2 cells and enterocytes from hiPSC. Biometals 30:643-661.

Senn, E., E. Scharrer, and S. Wolffram. 1992. Effects of glutathione and of cysteine on intestinal absorption of selenium from selenite. Biol. Trace Elem. Res. 33:103-108.

Sharma, N., N. K. Singh, O. P. Singh, V. Panday, and P. K. Verma. 2011. Oxidative stress and antioxidant status during transition period in dairy cows. Asian-Australas. J. Anim. Sci. 24:479-484.

Skřivan, M., M. Marounek, M. Englmaierová, and E. Skřivanová. 2012. Influence of dietary vitamin $\mathrm{C}$ and selenium, alone and in combination, on the composition and oxidative stability of meat of broilers. Food Chem. 130:660-664.

Sun, P., J. Wang, W. Liu, D. P. Bu, S. J. Liu, and K. Z. Zhang. 2017. Hydroxy-selenomethionine: A novel organic selenium source that improves antioxidant status and selenium concentrations in milk and plasma of mid-lactation dairy cows. J. Dairy Sci. 100:96029610 .

Thiex, N. J., S. Anderson, and B. Gildemeister. 2003. Crude fat, diethyl ether extraction, in feed, cereal grain, and forage (Randall/ Soxtec/submersion method): Collaborative study. J. AOAC Int. $86: 888-898$.

Thom, E. C. 1959. The discomfort index. Weatherwise 12:57-61.

Touyz, R. M. 2004. Reactive oxygen species, vascular oxidative stress, and redox signaling in hypertension: What is the clinical significance? Hypertension 44:248-252.

Van Soest, P. J., J. B. Robertson, and B. A. Lewis. 1991. Methods for dietary fiber, neutral detergent fiber, and nonstarch polysaccharides in relation to animal nutrition. J. Dairy Sci. 74:3583-3597.

Wang, C., Q. Liu, W. Z. Yang, Q. Dong, X. M. Yang, D. C. He, P. Zhang, K. H. Dong, and Y. X. Huang. 2009. Effects of selenium yeast on rumen fermentation, lactation performance and feed digestibilities in lactating dairy cows. Livest. Sci. 126:239-244.

Weiss, W. P. 2003. Selenium nutrition of dairy cows: Comparing responses to organic and inorganic selenium forms. Pages 333-373 in Proc. Proceeding of the 19th Alltech Annual Symposium Nutrition, Biotechnology Feed Food. Univ. Lexington, Nottingham, UK.

Zheng, D., R. Li, and W. Wang. 1982. A preliminary exposition on lowselenium zone in the world. Acta Sci. Circumstantiae 3:241-250. 